\title{
Plasticity of total and intracellular phosphorus quotas in Microcystis aeruginosa cultures and Lake Erie algal assemblages
}

\section{Matthew A. Saxton ${ }^{1 \dagger}{ }^{,}$Robert J. Arnold ${ }^{1}$, Richard A. Bourbonniere ${ }^{2}$, Robert Michael L. McKay ${ }^{3}$ and Steven W. Wilhelm ${ }^{1}$ *}

1 Department of Microbiology, University of Tennessee, Knoxville, TN, USA

${ }^{2}$ National Water Research Institute, Environment Canada, Burlington, ON, USA

${ }^{3}$ Department of Biological Sciences, Bowling Green State University, Bowling Green, OH, USA

\section{Edited by:}

George S. Bullerjahn, Bowling Green State University, USA

\section{Reviewed by:}

Assaf Sukenik, Israel Oceanographic and Limnological Research, Israel

Ilana R. Berman-Frank, Bar Ilan

University, Israel

\section{${ }^{*}$ Correspondence:}

Steven W. Wilhelm, Department of

Microbiology, The University of

Tennessee, M409 Walters Life

Sciences, Knoxville, TN 37996-0845,

USA.

e-mail:wilhelm@utk.edu

\section{${ }^{\dagger}$ Present address:}

Matthew A. Saxton, Keck

Environmental Laboratory,

Environmental Science and Policy

Program, College of William and

Mary, 200 Wake Drive, Williamsburg,

VA 25185, USA.
Blooms of the potentially toxic cyanobacterium Microcystis are common events globally, and as a result significant resources continue to be dedicated to monitoring and controlling these events. Recent studies have shown that a significant proportion of total cell-associated phosphorus $(P)$ in marine phytoplankton can be surface adsorbed; as a result studies completed to date do not accurately report the $\mathrm{P}$ demands of these organisms. In this study we measure the total cell-associated and intracellular P as well as growth rates of two toxic strains of Microcystis aeruginosa Kütz grown under a range of $\mathrm{P}$ concentrations. The results show that the intracellular $\mathrm{P}$ pool in Microcystis represents a percentage of total cell-associated $P(50-90 \%)$ similar to what has been reported for actively growing algae in marine systems. Intracellular $\mathrm{P}$ concentrations (39-147 $\mathrm{fg} \mathrm{cell}^{-1}$ ) generally increased with increasing $P$ concentrations in the growth medium, but growth rate and the ratio of total cell-associated to intracellular $\mathrm{P}$ remained generally stable. Intracellular $\mathrm{P}$ quotas and growth rates in cells grown under the different $\mathrm{P}$ treatments illustrate the ability of this organism to successfully respond to changes in ambient $P$ loads, and thus have implications for ecosystem scale productivity models employing $\mathrm{P}$ concentrations to predict algal bloom events.

\section{Keywords: cyanobacteria, phosphorus, Microcystis}

\section{INTRODUCTION}

Widespread nutrient loading has led to the eutrophication of aquatic ecosystems throughout the developed world. A primary concern linked to eutrophication is the appearance of harmful algal blooms (HABs). HAB events are well-documented, ecosystem-wide problems that can impact human health, kill livestock, foul potable water supplies, and compromise the integrity of both recreational and commercial fisheries (Carmichael, 2001). HABs have also been implicated in contributing to the formation of hypoxic zones (Paerl et al., 1998).

Efforts to limit algal bloom formation have historically focused on reducing nutrient loading. Phosphorus $(\mathrm{P})$ has been suggested to be the nutrient that limits phytoplankton growth in most freshwater ecosystems (Schindler, 1977; Schindler et al., 2008). Regulating P-loading has led to successes in controlling algal bloom formation in some eutrophic systems (Makarewicz and Bertram, 1991). This developing understanding of eutrophication has been critical to the continued development of mathematical environmental models which have become substantially more sophisticated with advances such as coupling hydrodynamic, ecological, and watershed models (Jørgensen, 2010).

Microcystis spp. are among the most common bloom-forming cyanobacteria in freshwaters and have a global distribution
(Chorus and Bartram, 1999). The effects of P limitation on Puptake in Microcystis have been extensively studied. Like other cyanobacteria, Microcystis possesses the ability to store excess $\mathrm{P}$ intracellularly, as polyphosphate granules, and P-starved cells have higher rates of P-uptake than P-sufficient cells (Jacobson and Halmann, 1982). Microcystis has been shown to respond to P limitation by rapid P-uptake with a notable increase in $V_{\max }$ observed under P-limiting conditions (Kromkamp et al., 1989). The recently sequenced Microcystis genomes indicate the presence of ATP driven P-uptake systems similar to what has been described in Synechococcus (Ritchie et al., 1997, 2001; Kaneko et al., 2007; Frangeul et al., 2008).

Recently, an oxalate rinse developed to remove surface adsorbed iron (Tovar-Sanchez et al., 2003) was shown to also effectively remove surface adsorbed $\mathrm{P}$ from marine plankton (SãnudoWilhelmy et al., 2004; Fu et al., 2005). Subsequently, these studies have shown a significant proportion (15-45\%) of total cellassociated $\mathrm{P}$ to be surface adsorbed in marine cyanobacteria, and that this $\mathrm{P}$ is likely associated with surface adsorbed manganese. These studies have also suggested surface adsorption of $\mathrm{P}$ may be part of a two-step process in which surface adsorption is followed by internalization. Arguably, this phenomenon, if universal in nature, is predicted to be of even greater relevance to freshwater 
ecosystems given their more universal P-limited nature. A consequence of the presence of adsorbed $\mathrm{P}$ on the surface of phytoplankton is that previous estimates of cyanobacterial $\mathrm{P}$ requirements may overstate the need for this nutrient. Alternatively, the ability of cyanobacteria to store $\mathrm{P}$ on their exterior surface may act as a novel strategy to allow persistence during periods of prolonged $\mathrm{P}$ deficiency (or to survive "boom-and-bust" cycles of nutrient availability). As such, a necessary first step is to determine the ability of cells to accumulate extracellular $\mathrm{P}$ and, further, to determine the contribution of this pool to estimated total P quotas.

In this study we determined the total cell-associated and intracellular P quotas and growth rates of two toxic Microcystis strains grown under a series of $\mathrm{P}$ concentrations. We similarly examined the ratio of total cell associated to intracellular $\mathrm{P}$ of natural communities in the western basin of Lake Erie where Microcystis forms an important part of the endemic plankton assemblage. Establishing accurate $\mathrm{P}$ quotas (and their plasticity) for this potentially toxic bloom-forming cyanobacterium is a necessary step toward the development of realistic environmental phytoplankton growth models and management strategies for many important freshwater resources.

\section{MATERIALS AND METHODS CYANOBACTERIAL CULTURE CONDITIONS}

Experiments were performed with M. aeruginosa PCC 7806 obtained from the Pasteur Culture Collection. While M. aeruginosa PCC 7806 is a globally used type strain, it is not representative of much of the observed Microcystis diversity in Lake Erie (Ouellette and Wilhelm, 2003; Ouellette et al., 2006; Ye et al., 2009). M. aeruginosa LE3, an isolate from Lake Erie (Brittain et al., 2000), was also included as it has been shown to be representative of Lake Erie Microcystis (e.g., Rinta-Kanto and Wilhelm, 2006) and has been used as a standard in numerous studies (e.g., RintaKanto et al., 2009b). Cultures were maintained in BG-11 medium
(Rippka et al., 1979) at $\mathrm{pH} 7.5$ with $\mathrm{P}$ concentrations ranging from 1.75 to $175 \mu \mathrm{M} \mathrm{K} \mathrm{HPO}_{4}$. Cultures were grown in $50 \mathrm{~mL}$ glass culture tubes (Kimble, Vineland, NJ, USA) at $24^{\circ} \mathrm{C}$ under continuous illumination of $\sim 30 \mu \mathrm{mol}$ photons $\mathrm{m}^{-2} \mathrm{~s}^{-1}$. Prior to use, all culture tubes were soaked overnight in $1 \% \mathrm{HCl}$ and rinsed multiple times with Milli-Q ${ }^{\circledR}$ water (Millipore Corp., Billerica, MA, USA). Samples were grown and transferred at experimental $\mathrm{P}$ concentrations two times prior to data collection. Multiple transfers were performed to ensure the stabilization of cellular $\mathrm{P}$ stores and the physiological equilibration of cell cultures to experimental P levels vis a vis Wilhelm et al. (1996). Cyanobacterial growth was monitored daily using a Turner Designs TD-700 fluorometer (Sunnyvale, CA, USA) equipped with an in vivo chl $a$ filter set (excitation $\lambda=340-500 \mathrm{~nm}$; emission $\lambda=>665 \mathrm{~nm}$ ). Growth rates were determined through the measurement of the slope of the growth curve during the exponential growth phase plotted as the natural log. All experiments were performed in triplicate unless otherwise noted.

\section{FIELD SAMPLE COLLECTION}

Field samples were collected at sites across Lake Erie (Table 1) between the dates of August 3 and 7, 2010 aboard the CCGS Limnos. Surface water was collected at each site using $10 \mathrm{~L}$ Niskin sampling bottles and subsequently stored in $3 \mathrm{~L}$ opaque amber polycarbonate bottles until filtration (with the time between collection and storage less than $1 \mathrm{~h}$ ).

\section{PHYTOPLANKTON ENUMERATION}

Phytoplankton enumeration was performed using samples preserved in Lugol's Iodine as previously described (Rodhe et al., 1958; Anderson, 2005). Fifty milliliter samples from each incubation were collected and immediately distributed into amber bottles with predispensed Lugol's Iodine resulting in a final concentration of $2 \%$ (vol/vol) fixative. Fixed samples were enumerated using a

Table 1 | Hydrological and biological parameters of surface water sampled from Lake Erie August 2010.

\begin{tabular}{|c|c|c|c|c|c|c|c|}
\hline Station & 478 & $970(357)$ & 973 & 882 & 1163 & 341 & $880(84)$ \\
\hline Location & $41^{\circ} 39^{\prime} 26^{\prime \prime}$ & $41^{\circ} 49^{\prime} 30^{\prime \prime}$ & $41^{\circ} 47^{\prime} 30^{\prime \prime}$ & $41^{\circ} 46^{\prime} 00^{\prime \prime}$ & $41^{\circ} 28^{\prime} 16^{\prime \prime}$ & $41^{\circ} 48^{\prime} 00^{\prime \prime}$ & $41^{\circ} 56^{\prime} 08^{\prime \prime}$ \\
\hline (Lat ${ }^{\circ}$, LongW) & $\left(82^{\circ} 49^{\prime} 01^{\prime \prime}\right)$ & $\left(82^{\circ} 58^{\prime} 30^{\prime \prime}\right)$ & $\left(83^{\circ} 20^{\prime} 00^{\prime \prime}\right)$ & $\left(83^{\circ} 18^{\prime} 30^{\prime \prime}\right)$ & $\left(82^{\circ} 43^{\prime} 05^{\prime \prime}\right)$ & $\left(82^{\circ} 17^{\prime} 30^{\prime \prime}\right)$ & $\left(81^{\circ} 39^{\prime} 14^{\prime \prime}\right)$ \\
\hline Extracellular P (\%) & 4.9 & 10.91 & 0.74 & 9.99 & 16.54 & 0 & 34.12 \\
\hline Total particulate $P\left(\mu \mathrm{gL}^{-1} \pm \mathrm{SD}\right)$ & $8.2 \pm 3.65$ & $8.16 \pm 3.65$ & $27.05 \pm 4.68$ & $13.18 \pm 0.91$ & $96.97 \pm 18.76$ & $6.28 \pm 0.86$ & $6.25 \pm 1.44^{*}$ \\
\hline Intracellular $P\left(\mu \mathrm{gL}^{-1} \pm \mathrm{SD}\right)$ & $7.3 \pm 2.78^{*}$ & $7.27 \pm 2.78^{*}$ & $26.85 \pm 0.80$ & $11.86 \pm 1.17$ & $80.93 \pm 13.20$ & $6.30 \pm 1.74$ & $4.12 \pm 0.099 *$ \\
\hline $\operatorname{SRP}\left(\mu g L^{-1}\right)$ & 0.8 & 1.1 & 1.3 & 1.7 & 2.1 & 0.4 & 0.6 \\
\hline $\operatorname{TDP}\left(\mu g \mathrm{~L}^{-1}\right)$ & 7.5 & 6.9 & 9.4 & 10.6 & 14.0 & 5.0 & 4.8 \\
\hline $\mathrm{TP}\left(\mu g \mathrm{~L}^{-1}\right)$ & 21.6 & 21.8 & 37.7 & 34.7 & 85.5 & 13.3 & 12.9 \\
\hline $\mathrm{NO}_{\mathrm{X}}^{-}\left(\mathrm{mgN} \mathrm{L}^{-1}\right)^{\mathrm{a}}$ & 0.25 & 0.145 & 0.017 & 0.016 & 0.010 & 0.073 & 0.059 \\
\hline $\mathrm{NH}_{3}\left(\mathrm{mgNL}^{-1}\right)$ & 0.011 & 0.010 & 0.009 & 0.016 & $\mathrm{BDL}^{\mathrm{b}}$ & 0.012 & 0.018 \\
\hline TDN (mg L ${ }^{-1}$ ) & 0.526 & 0.338 & 0.301 & 0.410 & 0.393 & 0.361 & 0.291 \\
\hline $\mathrm{PON}\left(\mathrm{mg} \mathrm{L}^{-1}\right)$ & 0.12 & 0.178 & 0.215 & 0.228 & 0.678 & 0.101 & 0.094 \\
\hline $\mathrm{SiO}_{2}\left(\mathrm{mg} \mathrm{L}^{-1}\right)$ & 1.46 & 1.53 & 1.77 & 2.00 & 3.61 & 1.53 & 0.28 \\
\hline $\mathrm{SO}_{4}^{2-}\left(\mathrm{mg} \mathrm{L}^{-1}\right)$ & 21.8 & 18.9 & 19.6 & 19.4 & 34.0 & 21.1 & 21.8 \\
\hline $\mathrm{POC}\left(\mathrm{mg} \mathrm{L}^{-1}\right)$ & 0.73 & 1.20 & 1.38 & 1.46 & 3.66 & 0.842 & 0.658 \\
\hline Total Chla $\left(\mu \mathrm{gL}^{-1} \pm \mathrm{SD}\right)$ & $6.1 \pm 0.13$ & $15.82 \pm 2.21$ & $18.61 \pm 0.61$ & $16.09 \pm 1.34$ & $16.25 \pm 0.52$ & $5.52 \pm 0.68$ & $7.54 \pm 0.74$ \\
\hline
\end{tabular}

${ }^{*}$ Indicates $n=2 .{ }^{a}$ Nitrate + nitrite as $N .{ }^{b} B D L$, below detectable limits $\left(<0.005 \mathrm{mgN} \mathrm{L}^{-1}\right)$. 
Sedgwick-Rafter counting slide (Wildco) on a Micromaster light microscope (ThermoFisher). Samples were allowed to settle in the counting chamber for 3-5 min prior to enumeration. Four horizontal passes were made across each slide encompassing the full height and width of the slide; no fewer than 40 fields of view were randomly selected across each slide. Each field of view was imaged and saved using Micron imaging software (Westover Scientific); the use of this software allowed for the measurement of the field of view.

\section{QUANTIFICATION OF TOTAL CELLULAR AND INTRACELLULAR P}

Total cellular and intracellular $\mathrm{P}$ concentrations were independently measured. Surface bound P was removed using an oxalate wash reagent initially designed for removal of iron (Tovar-Sanchez et al., 2003) and subsequently demonstrated to be applicable for removal of surface-sorbed P (Sãnudo-Wilhelmy et al., 2004). Aliquots of $5 \mathrm{~mL}$ from individual cultures and $50-200 \mathrm{~mL}$ from field samples were harvested onto pre-combusted $\left(450^{\circ} \mathrm{C}\right.$ for $\left.4 \mathrm{~h}\right)$ $25 \mathrm{~mm}$ Whatman (Kent, UK) GF/F glass fiber filters for the determination of total $\mathrm{P}$ in samples. The range in sample volumes collected at the individual sites was to account for different phytoplankton concentrations at each station. For the determination of intracellular P from Microcystis isolates, aliquots were first mixed with an equal volume of oxalate wash and allowed to incubate for 5 min prior to harvest. Field samples were filtered until approximately $5 \mathrm{~mL}$ of sample water remained in the filter unit; $5 \mathrm{~mL}$ of oxalate rinse was then applied and incubated for $5 \mathrm{~min}$. A top-up solution containing equal parts oxalate rinse and filtered lakewater was applied as needed to counter losses due to residual vacuum. Following this incubation, the filter was rinsed three times with $5 \mathrm{~mL}$ of P-free growth media or filtered lake water. To control for the removal of surface associated $\mathrm{P}$ during the washing process, control samples were rinsed with P-free medium or filtered lake water four times in the same manner as experimental samples. Unused growth medium of each of the experimental P concentrations was passed through filters and rinsed with P-free media and oxalate rinse solution as blanks to control for media associated $\mathrm{P}$ binding to the filter. Filtered station water was used as blanks for field samples. All treatments were performed in triplicate and blanks were performed in duplicate. Following the oxalate rinse procedure, filters were stored at $-20^{\circ} \mathrm{C}$ until analysis.

\section{P MEASUREMENT}

Particulate organic $P$ was collected on filters and converted to inorganic $\mathrm{P}$ via persulfate oxidation (Menzel and Corwin, 1965; Wetzel and Likens, 2000). Freshly made 5\% potassium persulfate solution was added to samples that were then placed in a boiling water bath for $1 \mathrm{~h}$. Total $\mathrm{P}$ concentrations were measured spectrophotometrically $(885 \mathrm{~nm})$ using the ammonium molybdate method (Wetzel and Likens, 2000). All measurements for field samples were performed on a Thermo Spectronic Genesys 20 spectrophotometer (ThermoFisher Waltham, MA, USA), whereas cultured samples were processed using a Biomate 5 spectrophotometer (ThermoFisher Waltham, MA, USA).

Field samples were prepared by first digesting with $5 \%$ potassium persulfate, followed by autoclaving for $30 \mathrm{~min}$. Total $\mathrm{P}$ was spectrophotometrically analyzed $(880 \mathrm{~nm})$ with the molybdate ascorbic acid method (Strickland and Parsons, 1972) using a 10-cm quartz cell and a Cary 50 UV-vis spectrophotometer (Varian Palo Alto, CA, USA). A calibration was conducted using phosphate reference standards of known concentration processed in the same manner as sample material. Individual replicates were omitted from field sample analysis if one sample was more than $100 \%$ different than the average of the two other samples. Variability among replicates was likely the result of the incomplete rinsing of cell aggregates.

Subsamples of cultured samples $(1.5 \mathrm{~mL})$ were also collected from each tube for direct counts of cell concentration. Microcystis cell densities were determined by epifluorescence microscopy with a Leica (Wetzlar, Germany) DMXRA epifluorescence microscope using the Texas Red filter set targeting accessory pigment (phycobillin) autofluorescence as previously described (Wilhelm et al., 2006). This was performed to normalize P measurements to Microcystis cell abundance.

\section{WATER CHEMISTRY}

Samples for nutrients, including total dissolved phosphorus (TDP), soluble reactive phosphorus (SRP), total dissolved nitrogen (TDN), $\mathrm{NH}_{4}^{+}-\mathrm{N}, \mathrm{NO}_{3}^{-}-\mathrm{N}+\mathrm{NO}_{2}^{-}-\mathrm{N}$, silicate $\left(\mathrm{SiO}_{2}\right)$, sulfate $\left(\mathrm{SO}_{4}^{2-}\right)$, particulate organic nitrogen ( $\left.\mathrm{PON}\right)$, and particulate organic carbon (POC), were collected and stored at $4^{\circ} \mathrm{C}$ until analysis. Analysis was conducted at the National Laboratory for Environmental Testing (Environment Canada) using their standard techniques (NLET, 1994).

\section{EXTRACTED CHLOROPHYLL a}

Chlorophyll $a(\operatorname{chl} a)$ concentration at field stations was determined as a proxy for total phytoplankton biomass. Seston was filtered through $0.2-\mu \mathrm{m}$ nominal pore-size polycarbonate membranes. Chla concentrations were determined using the nonacidification method (Welschmeyer, 1994) following extraction in $90 \%$ acetone overnight at $-20^{\circ} \mathrm{C}$ using a Turner Designs $10-\mathrm{AU}$ fluorometer.

\section{RESULTS}

\section{P-CONSTRAINTS ON MICROCYSTIS GROWTH}

Cultured Microcystis growth rates across a range of $\mathrm{P}$ concentrations are shown in Table 2. Growth rates in both strains were only slightly variable across the tested experimental P concentrations. $M$. aeruginosa PCC 7806 growth rates ranged between 0.079 and 0.162 divisions day ${ }^{-1}$ with $M$. aeruginosa LE3 growth rates ranging from 0.058 to 0.142 divisions day $^{-1}$. Growth rates increased with a slope of 0.0002 in M. aeruginosa PCC 7806 while M. aeruginosa LE3 rates decreased with a slope of -0.0001 . Growth rates were especially steady among those cultures maintained at higher $\mathrm{P}$ concentrations. Growth rates were more variable in $M$. aeruginosa LE3 than in M. aeruginosa PCC 7806. Although growth rates were stable across concentrations of $\mathrm{P}$, biomass was notably lower in cultures maintained under the lower P concentrations (results not shown). It should also be noted that Microcystis PCC 7806 did not grow consistently at the lowest $\mathrm{P}$ concentrations in spite of repeated attempts. We recognize that the reported growth rates are lower than published values. These lower growth rates are the result of the cultures being grown in conditions not optimized to 
Table 2 | Microcystis aeruginosa strains PCC 7806 and LE3 growth rates.

\begin{tabular}{lll}
\hline Organism & $\begin{array}{l}\text { Growth media } \mathbf{P} \\
\text { concentration }(\boldsymbol{\mu M})\end{array}$ & $\begin{array}{l}\text { Growth rate } \\
\left.\mathbf{l d a y}^{-\mathbf{1}} \pm \mathbf{S D}\right)\end{array}$ \\
\hline M. aeruginosa PCC 7806 & 1.75 & $0.079^{*}$ \\
& 8.75 & $0.123 \pm 0.009$ \\
& 17.5 & $0.149 \pm 0.005$ \\
& 87.5 & $0.162 \pm 0.005$ \\
M. aeruginosa LE3 & 175 & $0.138 \pm 0.023$ \\
& 1.75 & $0.118 \pm 0.008$ \\
& 8.75 & $0.142 \pm 0.001$ \\
& 17.5 & $0.0844^{*}$ \\
& 87.5 & $0.058 \pm 0.001$ \\
& 175 & $0.108 \pm 0.001$ \\
\hline
\end{tabular}

Growth rates measured in triplicates except where ${ }^{*} n=1$ as replicates would not grow at these concentrations.

obtain maximum growth rates, but rather they best reflect natural conditions (lower than optimal temperature and light). It is also possible cultures may have became $\mathrm{CO}_{2}^{-}$limited as a result of small culture volume.

\section{TOTAL CELL-ASSOCIATED AND INTRACELLULAR P QUOTAS IN CULTURED MICROCYSTIS}

To obtain accurate intracellular $\mathrm{P}$ quotas for Microcystis aeruginosa, we utilized the oxalate rinse technique to differentiate between the total cell-associated and intracellular $\mathrm{P}$ pools (Figure 1). The range of total cell-associated $\mathrm{P}$ concentrations reported here $\left(39-173 \mathrm{fg} \mathrm{cell}^{-1}\right)$ are within the range of previously reported values (29-433 $\mathrm{fg}$ cell $^{-1}$; Rhee and Gotham, 1980; Sbiyyaa et al., 1998; Tsukada et al., 2006; Shen and Song, 2007). As was anticipated, intracellular P quotas (34-146 $\mathrm{fg}$ cell $^{-1}$ ) were significantly smaller (ANOVA $p=0.001$ ) than the cell-associated values $\left(39-173 \mathrm{fg}\right.$ cell $\left.^{-1}\right)$. As had been previously reported for marine cyanobacteria (Fu et al., 2005), our results show that surface adsorbed $\mathrm{P}$ represents a significant portion (between 10 and $50 \%$ ) of total cell-associated P in Microcystis. We also found that this percentage is stable across growth conditions in each of the strains tested (Figure 1C).

\section{TOTAL CELL-ASSOCIATED AND INTRACELLULAR P IN NATURAL SAMPLES}

The ratio of total cell-associated $\mathrm{P}$ to intracellular $\mathrm{P}$ was also investigated in natural phytoplankton communities. Samples were collected across Lake Erie with specific emphasis on the Western Basin. This sampling focus reflects the recurrence of Microcystis blooms in this region (Rinta-Kanto et al., 2005, 2009a; Moorhead et al., 2008). Microcystis spp. was present at all tested stations, though a diverse assemblage of cyanobacteria and eukaryotic algae were observed (Table A1 in Appendix). Hydrological and biological parameters measured as part of this study were similar to those previously reported across Lake Erie (Table 2; DeBruyn et al., $2004)$. Intracellular P made up an average of $89 \%( \pm 11 \%)$ with a range of $0-65 \%$ of total particulate $\mathrm{P}$ in these samples (Table 1 ).

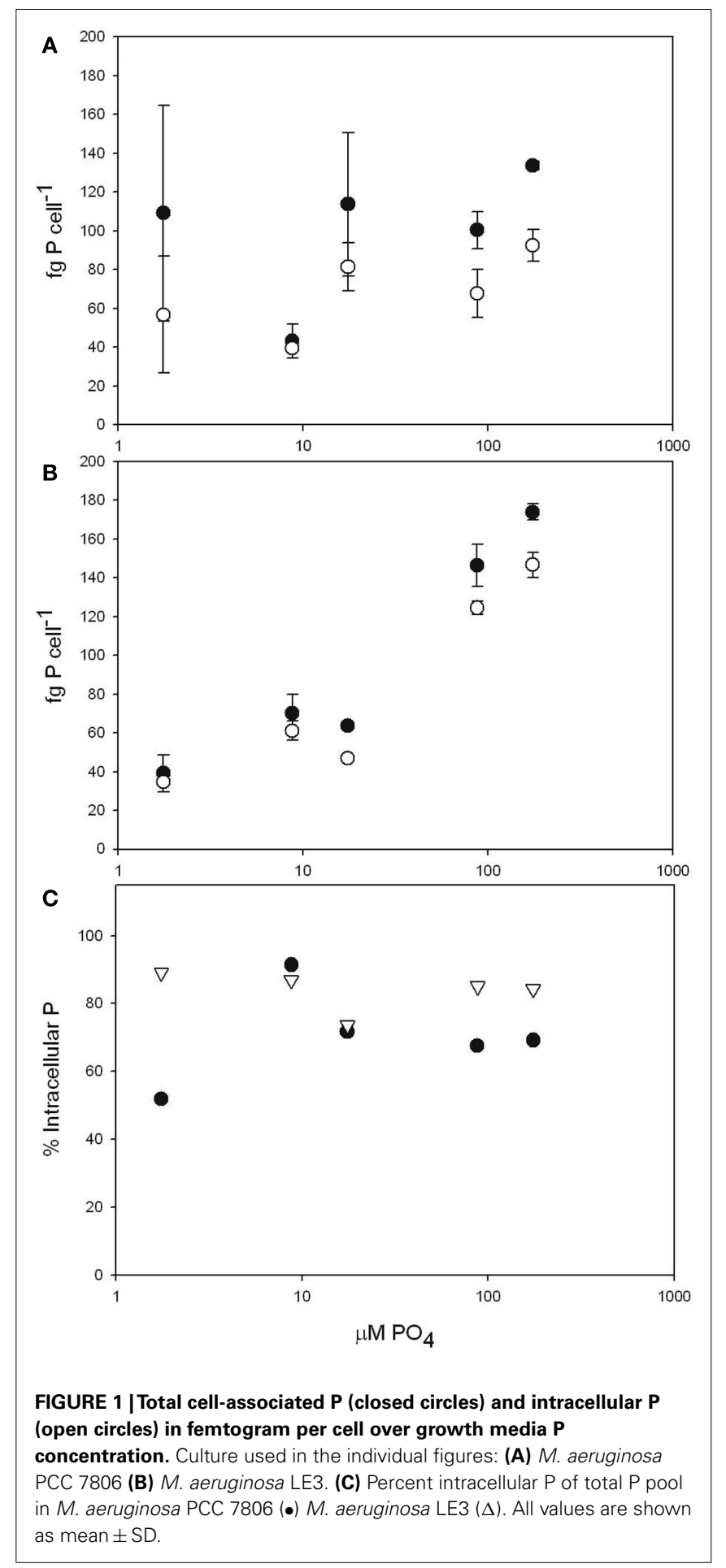

Pearson correlation analysis of Western Basin samples showed weakly significant correlations $(p<0.1)$ between the proportion of surface associated extracellular $\mathrm{P}$ and several environmental variables, including SRP, POC, $\mathrm{PON}$, and $\mathrm{SiO}_{2}$ (Table 3). Notably, no significant correlation was observed between the proportion of extracellular P and either TP or TDP (Table 3; Figure 2). 
Table 3 | Pearson correlation analysis results comparing the extracellular percentage of total particulate $P$ to hydrological and biological parameters.

\begin{tabular}{lll}
\hline & $\boldsymbol{r}$ & $\boldsymbol{p}$ \\
\hline Total particulate P & 0.648 & 0.164 \\
Intracellular P & 0.619 & 0.189 \\
$\mathrm{SRP}$ & 0.784 & 0.065 \\
$\mathrm{TDP}$ & 0.714 & 0.111 \\
$\mathrm{TP}$ & 0.706 & 0.117 \\
$\mathrm{NO}_{\mathrm{X}}^{-} \mathrm{N}^{\mathrm{a}}$ & -0.169 & 0.748 \\
$\mathrm{NH}_{3}^{-} \mathrm{N}$ & -0.508 & 0.304 \\
$\mathrm{TDN}_{\mathrm{PON}}$ & 0.144 & 0.785 \\
$\mathrm{SiO}$ & 0.764 & 0.077 \\
$\mathrm{POC}$ & 0.733 & 0.09 \\
$\mathrm{Chla}$ & 0.757 & 0.081 \\
& 0.451 & 0.369
\end{tabular}

${ }^{a}$ Nitrate + nitrite as $N$

\section{DISCUSSION}

A general tenet of limnology is that $\mathrm{P}$ is the nutrient limiting phytoplankton biomass in many freshwater systems and that, by reducing $\mathrm{P}$ loading to eutrophic bodies of water, we can begin to control formation of algal blooms and biomass accumulation (Schindler et al., 2008). While the previous statement is a commonly held assumption (although not always true, e.g., Scott and McCarthy, 2010; Wilhelm et al., 2011), it is important to note that individual $\mathrm{HAB}$ organisms have specific nutrient needs and differ in their abilities to assimilate nutrients from different chemical species. For example, it is now well established that some freshwater cyanobacteria possess the capacity to assimilate $\mathrm{P}$ from complex organic sources, such as phosphonates (Ilikchyan et al., 2009; Saxton et al., 2011). Moreover, the addition of organic sources of nutrient have been shown to influence phytoplankton community structure in bioassays performed using natural assemblages (Wang et al., 2010). To this end, we examined the P requirements of one of the most prominent bloom-forming cyanobacteria, M. aeruginosa, so as to develop a dynamic cellular quota that can be used to inform credible data reporting. To do so, we applied recently developed techniques that allow for the individual analysis of total cell-associated vs. intracellular P pools in phytoplankton.

Our results show plasticity in both cellular and surface absorbed $\mathrm{P}$ quotas. The ability to adjust intracellular $\mathrm{P}$ levels while maintaining a stable growth rate across a range of $\mathrm{P}$ concentrations is important for bloom-forming cyanobacteria as it allows for persistence in conditions that do not allow for the accumulation of significant biomass. This nutritional flexibility is important for microbes in environments that experience large nutrient variability, such as large lakes and estuarine systems. The plasticity of cellular P quotas is in contrast to the stability of the total cellassociated $\mathrm{P}$ to intracellular $\mathrm{P}$ ratio. Our data show this ratio to be stable, demonstrating an ability of Microcystis to adjust its P needs. These observations imply that surface associated $\mathrm{P}$ is a function of the external concentration in the environment. One potential route for $\mathrm{P}$ adjustment has been described in marine cyanobacteria that substitute phospholipids for nitrogen and sulfur containing

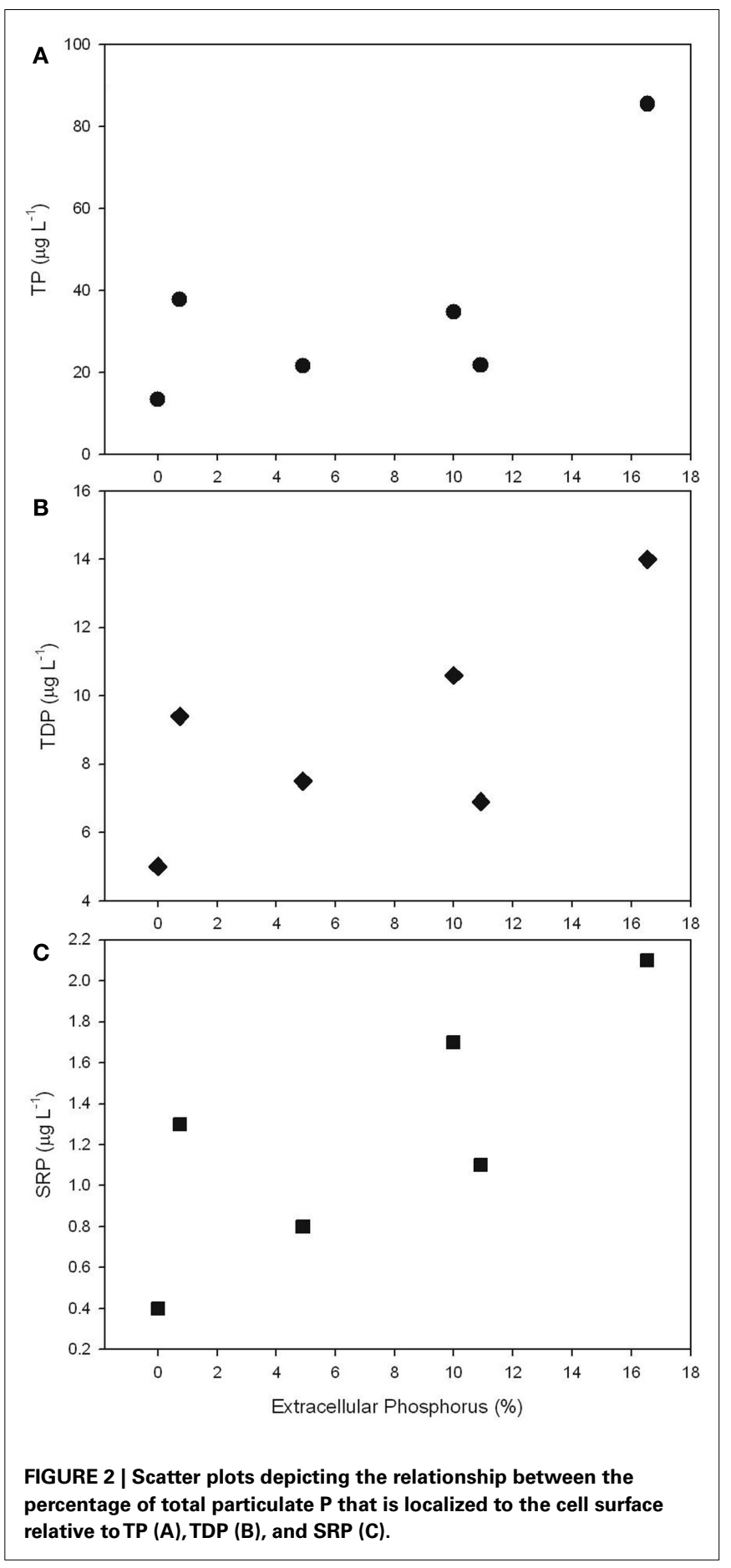

lipids in response to P limitation (Van Mooy et al., 2009), though this ability has not yet been described in Microcystis. Observed variability in $\mathrm{P}$ quota values in the tested strains is likely attributable to variance between strains. This variance is also observed in genetic differences between the sequenced Microcystis strains (Kaneko et al., 2007; Frangeul et al., 2008).

In contrast to our observations in cultured Microcystis, the ratio of intracellular to extracellular P was not constant between Lake Erie stations. 
Whereas this variability is correlated to differences in ambient SRP concentrations, dissimilarity in plankton communities between these sites may also contribute. The high proportion of intracellular $\mathrm{P}$ as compared to the total $\mathrm{P}$ pool in Lake Erie is indicative of an actively growing phytoplankton community (Sãnudo-Wilhelmy et al., 2004). Another factor influencing the intracellular-total $\mathrm{P}$ ratio in natural Microcystis populations may be colony morphology. If exposure to dissolved phosphate is a driver of the presence of extracellular $\mathrm{P}$, as is suggested by the positive correlation between SRP and the percentage of extracellular $\mathrm{P}$, then the cellular surfaces not exposed to the environment will not have externally bound $P$.

Unfortunately the fate of stored $\mathrm{P}$ on the cell surface remains elusive; it is possible that when cells are shifted from P-replete to P-limiting conditions, this surface associated material can be assimilated by cells as opposed to the alternative of this $\mathrm{P}$ being lost back to the environment as has been previously hypothesized (Sãnudo-Wilhelmy et al., 2004). While the hypothesis that surface adsorbed $\mathrm{P}$ is available to phytoplankton is intriguing, we observed no evidence to suggest that it is the case in Microcystis. Were this true we would expect the ratio of surface-intracellular $\mathrm{P}$ to shift toward the intracellular fraction under conditions of $\mathrm{P}$ stress as the cells scavenged $\mathrm{P}$ from the surface. However, we observed this ratio to remain constant across the growth conditions tested in this study. This observation paired with the positive correlation between SRP and surface adsorbed P in our Lake Erie samples suggests that the presence of $\mathrm{P}$ on the surface of these cells is a by-product of living in an environment where dissolved P is present.

Models of eutrophication and phytoplankton growth remain a critical tool for systems managers attempting to control frequent bloom formation and have been applied to Lake Erie since the middle of the twentieth century (Di Toro et al., 1975; Léon et al., 2005; Zhang et al., 2008; Schwab et al., 2009). Microcystis growth has been specifically targeted in many models because it is a problematic, bloom-forming cyanobacterium. Physiological parameters, such as cellular nutrient quotas, nutrient uptake rates and cellular growth rates, are integral to generating accurate predictions of cellular growth and toxin production under specific environmental conditions. Cellular $\mathrm{P}$ quota is a variable used (or is integral to variables used) in environmental models that have been applied to both Microcystis and Lake Erie (Robson and Hamilton, 2004; Léon et al., 2011; Burger et al., 2008; Trolle et al., 2008). This use of $\mathrm{P}$ quota as a modeling variable coupled with the fact that

\section{REFERENCES}

Anderson, R. A. (ed.). (2005). Algal Culturing Techniques. Boston: Academic Press.

Brittain, S. M., Wang, J., BabcockJackson, L., Carmichael, W. W., Rinehart, K. L., and Culver, D. A. (2000). Isolation and characterization of microcystins, cyclic heptapeptide hepatotoxins from a Lake Erie strain of Microcystis aeruginosa. J. Great Lakes Res. 26, 241-249.

Burger, D. F., Hamilton, D. P., and Pilditch, C. A. (2008). Modelling

literature P quotas in Microcystis do not take into account the presence of externally bound $\mathrm{P}$ hinders the ability of these models to accurately project the occurrence of blooms and underestimates the algal biomass that can be supported by current $\mathrm{P}$ inputs. For example, the minimum internal $p$ value applied to the CAEDYM model by Robson and Hamilton (2004) of $0.4 \mathrm{mg} \mathrm{P}(\mathrm{mg} \mathrm{chl} a)^{-1}$ represents approximately a $40 \times$ overestimation of the $\mathrm{P}$ needs of this organism compared to the values reported here. The accurate prediction of natural conditions by environmental models is dependent on the use of precisely measured variables, so it is critical that the modeling community use the most appropriate values. Moreover, the significant metabolic plasticity with respect to $\mathrm{P}$ quotas demonstrated by Microcystis in the present study is also not taken into account in current models. The current mathematical models use one or two values, often the minimum and maximum, to describe biological parameters such as growth rate or internal P quota (to limit the complexity of already complex models). Microcystis, however, has the ability to adapt to environmental challenge. As such, the ability of new hydrodynamic models, such as ELCOM, to more effectively describe changing physical conditions and nutrient concentrations in the water column suggest biological models would benefit from incorporating a more complex view of cyanobacterial growth over nutrient and temperature gradients.

The importance of controlling the growth of HAB cyanobacteria cannot be understated because of the water quality effects in both undeveloped and industrial countries. Previous studies examining $\mathrm{P}$ quotas in Microcystis measured only the total cell-associated $\mathrm{P}$ pool. In this study we differentiate between the total cell-associated $\mathrm{P}$ pools, including surface bound $\mathrm{P}$, and the intracellular $\mathrm{P}$ pool; thus the $\mathrm{P}$ quotas reported here are a more representative examination of the $\mathrm{P}$ needs of Microcystis than has been previously reported. These results will be useful to resource managers attempting to model and control this nuisance alga.

\section{ACKNOWLEDGMENTS}

We thank Michael Schultz for processing particulate organic phosphorus samples and Jennifer DeBruyn for aid with statistical analyses. We would also like to thank the captain and crew of the CCGS Limnos. This research was supported by NOAA Oceans and Human Health external grant NA05NO54781251, Ohio Sea Grant College Program award R/ER-73, and NSF-IOS \#0841918 and NSF-CBET\#0826838).

DeBruyn, J. M., Leigh-Bell, J. A., Mckay, R. M. L., Bourbonniere, R. A., and Wilhelm, S. W. (2004). Microbial distributions and the impact of phosphorus on bacterial activity in Lake Erie. J. Great Lakes Res. 30, 166-183.

Di Toro, D. M., O'Connor, D. J., Thomann, R. V., and Mancini, J. L. (1975). "A preliminary phytoplankton-zooplankton-nutrient model of western Lake Erie," in Systems Analysis and Simulation in Ecology, ed. B. C. Patten (New York, NY: Academic Press), 423-474.
Frangeul, L., Quillardet, P., Castets, A.M., Humbert, J.-F., Matthijs, H., Cortez, D., Tolonen, A., Zhang, C.C., Gribaldo, S., Kehr, J.-C., Zilliges, Y., Ziemert, N., Becker, S., Talla, E., Latifi, A., Billault, A., Lepelletier, A., Dittmann, E., Bouchier, C., and Tandeau De Marsac, N. (2008). Highly plastic genome of Microcystis aeruginosa PCC 7806, a ubiquitous toxic freshwater cyanobacterium. BMC Genomics 9, 274. doi:10.1186/1471-2164-9-274

Fu, F. X., Zhang, Y. H., Leblanc, K., Sanudo-Wilhelmy, S. A., and 
Hutchins, D. A. (2005). The biological and biogeochemical consequences of phosphate scavenging onto phytoplankton cell surfaces. Limnol. Oceanogr. 50, 1459-1472.

Ilikchyan, I. N., Mckay, R. M. L., Zehr, J. P., Dyhrman, S. T., and Bullerjahn, G. S. (2009). Detection and expression of the phosphonate transporter gene $\mathrm{phnD}$ in marine and freshwater picocyanobacteria. Environ. Microbiol. 11, 1314-1324.

Jacobson, L., and Halmann, M. (1982). Polyphosphate metabolism in the blue-green alga Microcystis aeruginosa. J. Plankton Res. 4, 481-488.

Jørgensen, S. E. (2010). A review of recent developments in lake modelling. Ecol. Modell. 221, 689-692.

Kaneko, T., Narajima, N., Okamoto, S., Suzuki, I., Tanabe, Y., Tamaoki, M., Nakamura, Y., Kasai, F., Watanabe, A., and Kawashima, K. (2007). Complete genomic structure of the bloom-forming toxic cyanobacterium Microcystis aeruginosa NIES-843. DNA Res. 14, 247-256.

Kromkamp, J., Vandenheuvel, A., and Mur, L. R. (1989). Phosphorus uptake and photosynthesis by phosphate-limited cultures of the cyanobacterium Microcystis aeruginosa. Br. Phycol. J. 24, 347-355.

Léon, L. K., Imberger, J., Smith, R. E. H., Hecky, R. E., Lam, D. C. L., and Schertzer, W. M. (2005). Modeling as a tool for nutrient management in Lake Erie: a hydrodynamics study. J. Great Lakes Res. 31, 309-318.

Léon, L. F., Smith, R. E. H., Hipsey, M. R., Bocaniov, S. A., Higgins, S. N., Hecky, R. E., Antenucci, J. P., Imberger, J. A. and Guildford, S. J. (2011). Application of a 3D hydrodynamic-biological model for seasonal and spatial dynamics of water quality and phytoplankton in Lake Erie. J. Great Lakes Res. 37, 41-53.

Makarewicz, J. C., and Bertram, P. (1991). Evidence for the restoration of the Lake Erie ecosystem. Bioscience 41, 216-223.

Menzel, D. W., and Corwin, N. (1965). The measurement of total phosphorus in seawater based on the liberation of organically pound fractions by persulfate oxidation. Limnol. Oceanogr. 10, 280-282.

Moorhead, D., Bridgeman, T., and Morris, J. (2008). "Changes in water quality of Maumee Bay 1928-2003," in Checking the Pulse of Lake Erie, eds M. Munawar and R. Heath (New Delhi: Backhuys Publishers), 123-158.
NLET. (1994). Manual of Analytical Methods, Vol. 1, Major Ion and Nutrients. Burlington, ON: Environment Canada.

Ouellette, A. J. A., Handy, S. M., and Wilhelm, S. W. (2006). Toxic Microcystis is widespread in Lake Erie: PCR detection of toxin genes and molecular characterization of associated cyanobacterial communities. Microb. Ecol. 51, 154-165.

Ouellette, A. J. A., and Wilhelm, S. W. (2003). Toxic cyanobacteria: the evolving molecular toolbox. Front. Ecol. Environ. 7, 359-366.

Paerl, H. W., Pinckney, J. L., Fear, J. M., and Peierls, B. L. (1998). Ecosystem responses to internal and watershed organic matter loading: consequences for hypoxia in the eutrophying Neuse river estuary, North Carolina, USA. Mar. Ecol. Prog. Ser. 166, 17-25.

Rhee, G. Y., and Gotham, I. J. (1980). Optimum N-P ratios and coexistence of planktonic algae. J. Phycol. $16,486-489$.

Rinta-Kanto, J. M., Konopko, E. A., Debruyn, J. M., Bourbonniere, R. A., Boyer, G. L., and Wilhelm, S. W. (2009a). Lake Erie Microcystis: relationship between microcystin production, dynamics of genotypes and environmental parameters in a large lake. Harmful Algae 8, 665-673.

Rinta-Kanto, J. M., Saxton, M. A., Debruyn, J. M., Smith, J. L., Marvin, C. H., Krieger, K. A., Sayler, G. S., Boyer, G. L., and Wilhelm, S. W. (2009b). The diversity and distribution of toxigenic Microcystis spp. in present day and archived pelagic and sediment samples from Lake Erie. Harmful Algae 8, 385-394.

Rinta-Kanto, J. M., Ouellette, A. J. A., Boyer, G. L., Twiss, M. R., Bridgeman, T. B., and Wilhelm, S. W. (2005). Quantification of toxic Microcystis spp. during the 2003 and 2004 blooms in western Lake Erie using quantitative realtime PCR. Environ. Sci. Technol. 39, 4198-4205.

Rinta-Kanto, J. M., and Wilhelm, S. W. (2006). Diversity of microcystinproducing cyanobacteria in spatially isolated regions of Lake Erie. Appl. Environ. Microbiol. 72, 5083-5085.

Rippka, R., Derulles, J., Waterbury, J. B., Herdman, M., and Stanier, R. Y. (1979). Generic assignments, strain histories and properties of pure cultures of cyanobacteria. J. Gen. Microbiol. 111, 1-61.

Ritchie, R. J., Trautman, D. A., and Larkum, A. W. D. (1997). Phosphate uptake in the cyanobacterium Synechococcus R-2 PCC 7942. Plant Cell Physiol. 38, 1232-1241.

Ritchie, R. J., Trautman, D. A., and Larkum, A. W. D. (2001). Phosphate limited cultures of the cyanobacterium Synechococcus are capable of very rapid, opportunistic uptake of phosphate. New Phytol. 152, 189-201.

Robson, B. J., and Hamilton, D. P. (2004). Three-dimensional modelling of a Microcystis bloom event in the Swan River estuary, Western Australia. Ecol. Modell. 174, 203-222.

Rodhe, W., Vollenweider, R. A., and Nauwerck, A. (1958). "The primary production and standing crop of phytoplankton," in Perspectives in Marine Biology, ed. A. A. BuzzatiTraverso (San Francisco: University of California Press), 299-322.

Sãnudo-Wilhelmy, S. A., Tovar-Sanchez, A., Fe, F. X., Capone, D. G., Carpenter, E. J., and Hutchins, D. A. (2004) The impact of surface-absorbed phosphorus on phytoplankton Redfield stoichiometry. Nature 432, 897-901.

Saxton, M. A., Morrow, E. A., Bourbonniere, R. A., and Wilhelm, S. W. (2011). Glyphosate influence on phytoplankton community structure in Lake Erie. J. Great Lakes Res. $37,683-690$.

Sbiyyaa, B., Loudiki, M., and Oudra, B. (1998). Nitrogen and phosphorus intracellular capacity in storage by Microcystis aeruginosa Kutz and Synechocystis sp.: toxic cyanobacteria occasionally forming blooms in Marrakesch area (Morocco). Ann. Limnol. Int. J. Limnol. 34 247-257.

Schindler, D. W. (1977). Evolution of phosphorus limitation in lakes. Science 195, 260-262.

Schindler, D. W., Hecky, R. E., Findlay, D. L., Stainton, M. P., Parker, B. R., Paterson, M. J., Beaty, K. G., Lyng, M., and Kasian, S. E. M. (2008). Eutrophication of lakes cannot be controlled by reducing nitrogen input: results of a 37year whole-ecosystem experiment. Proc. Natl. Acad. Sci. U.S.A. 105, 11254-11258.

Schwab, D. J., Beletsky, D., Depinto, J., and Dolan, D. M. (2009). A hydrodynamic approach to modeling phosphorus distribution in Lake Erie. $J$. Great Lakes Res. 35, 50-60.

Scott, J. T., and McCarthy, M. J. (2010). Nitrogen fixation may not balance the nitrogen pool in lakes over timescales relevant to eutrophication management. Limnol. Oceanogr. 53, 1265-1270.
Shen, H., and Song, L. R. (2007). Comparative studies on physiological responses to phosphorus in two phenotypes of bloom-forming Microcystis. Hydrobiologia 592, 475-486.

Strickland, J. D. H., and Parsons, T. R. (1972). A Practical Handbook of Seawater Analysis. Ottawa: Fisheries Research Board of Canada.

Tovar-Sanchez, A., Sãnudo-Wilhelmy, S., Garcia-Vargas, M., Weaver, R. S., Popels, L. C., and Hutchins, D. A. (2003). A trace metal clean reagent to remove surface-bound iron from marine phytoplankton. Mar. Chem. 82, 91-99.

Trolle, D., Skovgaard, H., and Jeppesen, E. (2008). The Water Framework Directive: setting the phosphorus loading target for a deep lake in Denmark using the 1D lake ecosystem model DYRESM-CAEDYM. Ecol. Modell. 219, 138-152.

Tsukada, H., Tsujimura, S., and Nakahara, H. (2006). Effect of nutrient availability on the $\mathrm{C}, \mathrm{N}$, and $\mathrm{P}$ elemental ratios in the cyanobacterium Microcystis aeruginosa. Limnology 7 , 185-192.

Van Mooy, B. A. S., Fredricks, H. F., Pedler, B. E., Dyhrman, S. T., Karl, D. M., Koblizek, M., Lomas, M. W., Mincer, T. J., Moore, L. R., Moutin, T., Rappe, M. S., and Webb, E. A. (2009). Phytoplankton in the ocean use non-phosphorus lipids in response to phosphorus scarcity. Nature 458, 69-72.

Wang, X., Qin, B., Gao, G., Wang, Y., Tang, X., and Otten, T. (2010). Phytoplankton community from Lake Taihu, China, has dissimilar responses to inorganic and organic nutrients. J. Environ. Sci. 22, 1491-1499.

Welschmeyer, N. A. (1994). Fluorometric analysis of chlorophyll-a in the presence of chlorophyll-b and pheopigments. Limnol. Oceanogr. 39, 1985-1992.

Wetzel, R. G., and Likens, G. E. (2000). Limnological Analyses. New York: Springer.

Wilhelm, S. W., Bullerjahn, G. S., Eldridge, M. L., Rinta-Kanto, J. M., Poorvin, L., and Bourbonniere, R. A. (2006). Seasonal hypoxia and the genetic diversity of prokaryote populations in the central basin hypolimnion of Lake Erie: evidence for abundant cyanobacteria and photosynthesis. J. Great Lakes Res. 32, 657-671.

Wilhelm, S. W., Farnsley, S. E., Lecleir, G. R., Layton, A. C., Satchwell, M. F., Debruyn, J. M., Boyer, G. L., Zhu, G., and Paerl, H. W. (2011). 
The relationship between nutrients, cyanobacterial toxin and the microbial community in Lake Tai (Taihu), China. Harmful Algae 10, 207-215.

Wilhelm, S. W., Maxwell, D. P., and Trick, C. G. (1996). Growth, iron requirements, and siderophore production in iron-limited Synechococcus PCC 7002. Limnol. Oceanogr. 41, 89-97.

Ye, W., Liu, X., Tan, J., Li, D., and Yang, H. (2009). Diversity and dynamics of microcystin - Producing cyanobacteria in Chinas third largest lake, Lake Taihu. Harmful Algae 8, 637-644.

Zhang, H., Culver, D. A., and Boegman, L. (2008). A two-dimensional ecological model of Lake Erie: Application to estimate dreissenid impacts on large lake plankton populations. Ecol. Modell. 214, 219-241.

Conflict of Interest Statement: The authors declare that the research was conducted in the absence of any commercial or financial relationships that could be construed as a potential conflict of interest.

Received: 18 October 2011; paper pending published: 23 November 2011; accepted: 03 January 2012; published online: 18 January 2012.

Citation: Saxton MA, Arnold RJ, Bourbonniere RA, McKay RML and Wilhelm SW (2012) Plasticity of total and intracellular phosphorus quotas in Microcystis aeruginosa cultures and Lake Erie algal assemblages. Front. Microbio. 3:3. doi: 10.3389/fmicb.2012.00003

This article was submitted to Frontiers in Aquatic Microbiology, a specialty of Frontiers in Microbiology.

Copyright () 2012 Saxton, Arnold, Bourbonniere, McKay and Wilhelm. This is an open-access article distributed under the terms of the Creative Commons Attribution Non Commercial License, which permits non-commercial use, distribution, and reproduction in other forums, provided the original authors and source are credited. 


\section{APPENDIX}

Table A1 | Abundance of selected phytoplankton genus determine via microscopic examination of samples collected from Lake Erie in August 2010.

\begin{tabular}{|c|c|c|c|c|c|c|c|}
\hline & 478 & $970(357)$ & 973 & 882 & 1163 & 341 & $880(84)$ \\
\hline Planktothrix spp. (filaments $\mathrm{mL}^{-1}$ ) & 149.96 & 449.89 & 1274.69 & 599.85 & 12222.04 & 1049.75 & 1049.75 \\
\hline Anabaena spp. (filaments $\mathrm{mL}^{-1}$ ) & ND & ND & ND & ND & 524.87 & ND & 74.98 \\
\hline Aulacosiera spp. (filaments $\mathrm{mL}^{-1}$ ) & ND & 149.96 & 74.98 & ND & 149.96 & ND & ND \\
\hline Fragilaria spp. (colonies $\mathrm{mL}^{-1}$ ) & ND & 74.98 & ND & 74.98 & ND & ND & 74.98 \\
\hline Chlamydomonas spp. (cells $\mathrm{mL}^{-1}$ ) & 224.95 & 74.98 & 149.96 & 74.98 & 74.98 & ND & ND \\
\hline Gloeocapsa spp. (colonies $\mathrm{mL}^{-1}$ ) & ND & ND & 74.98 & ND & ND & ND & 224.95 \\
\hline Closteriopsis spp. (cells $\mathrm{mL}^{-1}$ ) & ND & 74.98 & 149.96 & 149.96 & 149.96 & ND & ND \\
\hline Ceratium spp. (cells $\mathrm{mL}^{-1}$ ) & ND & ND & ND & ND & ND & ND & 74.98 \\
\hline
\end{tabular}

